\title{
Legal Protection of Traditional Cultural Expression as a Regional Asset in Yogyakarta
}

\author{
Dyah Permata Budi Asri \\ Faculty of Law, University of Janabadra, Yogyakarta, Indonesia \\ Email: dyah@janabadra.ac.id
}

\begin{abstract}
Cultural protection in Yogyakarta is very important due to its various cultures as well as source of local income, especially in culture-based tourism sector which becomes a leading sector in Yogyakarta. However ownership of these cultures has potency to be utilized and claimed without legitimate rights by other countries. Intellectual Property Rights (IPR) in Indonesia regulates traditional culture in the Act No. 28 Year 2014 on Copyright Traditional culture is stipulated in Chapter V about Traditional Cultural Expressions and Protected Creations, especially Article 38. Against the Expression of Traditional Culture, the State has obligation to maintain and to manage traditional culture as stated in Article 38, paragraph (2). The existence of the state obligation against all forms of Traditional Cultural Expression as stipulated in the Act on Copyright Number 28 Year 2014 has been mentioned explicitly. Daerah Istimewa Yogyakarta, which has tangible and intangible cultural diversity as well as considered as tourist destination, shall make efforts to protect the culture. Of course, this protection is not similar with the concept of Copyright or IPR in general, that is based on individual and pragmatical concept. However cultural protection should pay more attention to the concepts of communal society and collectivity in terms of ownership.
\end{abstract}

Keywords-Culture; legal protection; intellectual property rights

\section{INTRODUCTION}

Special Region of Yogyakarta, hereinafter referred to as Yogyakarta, has various cultures. For examples tangible cultures such as temples, sites, museums as well as intangible cultures such as arts, traditions, cultural values as well as traditional ceremonies. In Yogyakarta, the management of tangible culture has been regulated in various local regulations that are often refined to adjust the current situation and conditions, for example Mayor of Yogyakarta Regulation Number 43 of 2017 on the Determination and Elimination of Cultural Heritage of Yogyakarta City, Provincial Regulation of Yogyakarta Special Province Number 6 Year 2012 on Cultural Heritage Preservation and Cultural Heritage and other regulations. However, in relation to the intangible culture, the regulation is not sufficient and has not been well implemented. So far intangible culture regulation in Yogyakarta can been found in The Special Region of Yogyakarta regulation Number 3 of 2015 on Culture which is in the similar regulation with Cultural Heritage.

The importance of culture regulation in Yogyakarta occurs due to various reasons, such as Yogyakarta, is the third tourism destination after Bali and DKI Jakarta (National Bureau of Statistics, 2014). Yogyakarta has diversity of tradition and cultural ceremonies and Yogyakarta is supported also by the art creativity and community hospitality. Therefore, Yogyakarta is able to create various cultural and tourism products. Yogyakarta is attractive because of diversity of its existing cultures, which are more than 4,000 cultures, consisting of physical and non-physical cultures. Cultural diversity becomes community pride and market value for tourists in a region. Based on data of 2017, the number of foreigners who visit Yogyakarta in 2017 is approximately more than 4.8 million or increases more than $10 \%$ compared to the previous year [15]. Meanwhile, according to the Central Bureau of Statistics, the number of foreign and domestic tourists who visited Yogyakarta in 2016 is 4.5 million and increased more than 10\% compared to the data in 2015 [16].

Special Privileges Law of Yogyakarta No. 13 Year 2012 has strengthened the position and important role of Yogyakarta in maintaining, keeping and developing its culture, at local, regional and national levels. Yogyakarta has become an example of cultural development, especially Javanese culture, as well as a model of other cultural development in Indonesia. Cultural aspect has influenced the whole life of society and various sectors development in Yogyakarta including tourism sector.

The important reason for protecting culture in Yogyakarta is to maintain and to keep the culture from inappropriate uses by other parties or other countries. Issue on Indonesian culture protection becomes a hot issue these current years during claim of Reog Ponorogo and Pendet by Malaysia which was widely published in the mass media [1]. One of the cases is Indonesian cultural claim by Malaysia. In advertisement on the Discovery Channel called Enigmatic Malaysia, Pendet, puppet, and Reog Ponorogo are claimed as Malaysia's traditional asset [17]. In fact, claims to 
'cultural property' and heritage have led to conflicts and tensions between communities, regions and nations [2].

Potency of cultural claims in Yogyakarta will always occur, due to its attractive cultures, thus claim of culture as a local asset will still exist. This is the important reason to maintain cultural values in Yogyakarta as well as to preserve and to protect culture from various forms of violation. Protection and prevention towards the maintenance of culture in Yogyakarta would be good to maintain cultural preservation of indigenous peoples in DIY.

Culture is one creation produced by human intellectual ability, in this case customary law society as the creator, or the party that preserves and leaves the culture from generation to generation. Therefore, culture in Indonesia is also regulated by Act Number 28 Year 2014 on Copyright, where Copyright is one of Intellectual Property Rights. The Act on Copyright article 38 paragraph (1) to (4) regulates traditional cultural expression and protected rights (EBT). It is noted that government is responsible to maintain and to keep EBT; therefore EBT is government's responsibility. Culture is a human intellectual product; however, it is necessary to be distinguished with other human intellectual products. Culture is a collective / communal human intellectual product while other intellectual products are produced by individual. This research will analyze and assess government roles (local government where culture exists ) in culture as mandated by the Law on Copyright Article 38 Paragraph (2): "The State shall inventory, and maintain Traditional Cultural Expression as referred in paragraph (1) ". The focus of this research is intangible culture in Yogyakarta.

\section{RESEARCH METHOD}

This research is a normative juridical research. This normative juridical research is carried out by examining and interpreting theoretical matters related to principles, conceptions, doctrines and legal norms relating to the regulation of traditional cultural expressions in the regulation of Intellectual Property Rights. Data sources used in this research use primary data, namely data obtained from the field through observation, interviews, and data obtained from reliable sources, which are processed by researchers. In addition there are secondary data sources in this study in the form of data taken from library materials consisting of 3 (three) sources of legal material, namely primary, secondary and tertiary legal materials. Analysis of the data used in this research is qualitative analysis and conclusions are made by an inductive method, that is, things that are specifically then draw general conclusions according to the problem discussed in this research.

\section{RESULT AND DISCUSSION}

\section{A. Traditional Cultural Expression Regulation in the Act} Number 28 of 2014 on Copyright

Traditional cultural regulation in the Copyright Law has been enacted since 1982 Under the new Act on Copyright Year 2014, a new terminology namely Traditional Cultural Expression (EBT) is used while in the previous copyright law the Folklore term is used.

The EBT regulation is stipulated in Article 38 Paragraphs (1), (2), (3) and (4) of Copyright Law Number 28 of 2014 as follows:

(1) The Copyright of Traditional Cultural Expression is held by the State

(2) The State shall inventory, preserve and maintain Traditional Cultural Expression as referred in paragraph (1).

(3) The Use of Traditional Cultural Expression as referred in paragraph (1) shall take into account the values of society.

(4) Further provisions concerning the Copyright held by the State regarding Traditional Cultural Expressions as referred in paragraph (1) shall be governed by a Government Regulation.

There is an obligation to appoint a competent authority as Copyright holders of the EBT. Unknown EBT in Indonesia will be managed by state, therefore state has exclusive right on these EBT. However, this regulation might be difficult to be implemented since there is no further information about designated institutions, their functions and responsibilities. In the Copyright Law Number 28 of 2014, the notion of the creator doesn't have individual rights only, but in some articles, it is clearly stated that community is as copyright holder of traditional cultural expression of a certain group of indigenous peoples . The EBT is collective and is often considered as the property of the whole community, and does not belong to any individual in the community, also it is inherited traditionally by generation to generation. EBT is also a creation, innovation, and cultural expression that is generally hereditary and usually associated with a particular community or region, and grow in accordance with environmental changes. It is recognized that indigenous persons are entitled to the protection of their culture as part of their right to self-determination [8].

The Copyright Law offers the concept of individual liberalism protection while the EBT embraces the communal principle of togetherness, which is incompatible with the spirit of the law. Therefore its application becomes unclearly where the protection aspect of EBT is different from the concept of copyright protection. In addition, until now the EBT regulation in the Copyright Law has not been followed by Regulation on the management of EBT in Indonesia. The emergence of many disputes in the field of intellectual property rights signify all this time, the concept used in the protection of culture the local still cannot be applied optimally, or even possible there are no technical regulations 
regarding the existing problems especially those that regulate the problem [3], [4]. So in the end, in the absence of regulation, it can provide an opportunity for other parties to claim the communal property right belonging to the traditional community, which is known as EBT.

\section{B. The Importance of Legal Protection against Traditional Cultural Expression}

Traditional Cultural Expressions/ Expressions of Folklore as a traditional Intellectual Property, has cultural value as a cultural heritage that is growing, maintained and implemented to date, even in modern society worldwide. Indonesian culture has promising economic potential especially tourism and creative economic industry in Indonesia. In the area of the tourism industry, for example, tourism industry in Bali is based on Traditional Cultural Expression and has contribution to local income and make Bali known worldwide. In the area of creative economy industry, handicraft such as, batik, woodcarving, copper carving, silver has contribution to country's foreign exchange [12]. Everyone has the right to the protection of the moral and material interests resulting from any scientific, literary or artistic production of which he is the author [9].

EBT which is derived from local wisdom values of a particular group of people is usually inherited from generation to generation. The values of local wisdom are usually tangible and intangible culture that belong to community and difficult to identify their creator. Therefore, the Law on Intellectual Property is not able to protect EBT. According to WIPO, the owner of EBT are people who create, develop, and practice Traditional Cultural Expressions and Traditional Knowledge in traditional rules and concepts. Indigenous peoples, local people, and the state are the owners of the EBT. Thus, in the protection of local wisdom, common interest is always put forward than individual interests [11]. Intellectual Property is costly, time-consuming and requires an acceptable level of novelty or originality [6]. However, when intellectual property exists, it is relative inexpensive and easy to recreate. In addition, there may be no limit to how much Intellectual Property can be replicated, with similar value as its original product.

Context of legal protection is to protect human rights in order to give security to community [13]. Development of modern technology, especially in the area of telecommunications causes inappropriate use of existing EBT. Various commercialization of EBT occur at global level. This commercialization causes also distortion, alteration or modification of Traditional Cultural Expression inappropriately [12]. From a normative economic perspective, protection of TCE can be justified. It may prevent negative effects on the traditional owners holding TCE via acts of misappropriation [5]. Several cases of traditional cultural expression exploitation at international level has promoted the importance of legal system to protect the rights and interests of indigenous people against misappropriate use of cultures. In addition, the EBT system supports the establishment of a good documentation system for human creativity. $\mathrm{T}$ It is expected that good documentation can be used to support the creators (in this case the customary law community) or to refine EBT in order to provide higher added value, to the copyright.

\section{Implementation of Traditional Cultural Expression Management in Yogyakarta}

Currently in Yogyakarta, there is no available regulation such as Local Regulations for implementation of inventory and documentation activities [3], [4].. To support management of various cultures in Yogyakarta, the Local Government in Yogyakarta has regulation on traditional culture. The regulation is the Regulation of the Governor of Yogyakarta Special Region Number 21 of 2017 on the Use of the Jogjamark Brand, 100\% Jogja and Jogja Tradition As Co-Branding of Regional Products, which includes Jogjamark, 100\% Jogja and Jogja Tradition which have been registered to the Directorate General of Intellectual Property Ministry of Law and Human Rights Republic of Indonesia. The use of Jogjamark brand will surely protect the local culture in Yogyakarta from claims of ownership by other regions. Co-branding registration was made by the local government of Yogyakarta on behalf of the Governor of Yogyakarta. The agency that facilitated the Co-Branding Facility in Yogyakarta is the Department of Industry and Commerce of Yogyakarta through Technical Service Unit Business Services and Intellectual Property Management.

Efforts to protect EBT in Yogyakarta have been done preventively through legal protection. Thislegal protection which is provided by the government aims to prevent EBT prior to the violation, by conducting inventory and documentation process on EBT in Yogyakarta. Since 2013, Provincial Cultural Office in Yogyakarta has carried out cultures inventory. There are 22 local culture that have been registered as intangible cultural heritage namely Wayang Beber (2013); Wayang Mataraman Wayang (2013); Kancil Puppet (2013); Sekaten (2014); Pawukon (2014); Bedhaya Semang (2014); Gamelan Yogyakarta Style (2014); Daluang Paper (2014); Mubeng Beteng (2015); Gamping / Bekakak Saparan (2015); Gudeg (2015); Joglo Yogyakarta (2015); Kasongan Gebarah Handicraft (2015); Suran Mbah Demang (2016); Tawur Kesanga (2016); Labuhan Keraton (2016); Jathilan Yogyakarta (2016); Langendriyo (2016); Angguk Dance (2016); Langen Mandra Wanara (2016); Bakpia Yogyakarta (2016); and Lurik Yogyakarta (2016). Upon recognition of national cultural heritage, thus Cultural Office in Yogyakarta will propose those cultures as World Cultural Heritage through World Heritage Center UNESCO. The Convention on diversity of cultural expressions, adopted by United Nations Educational, Scientific and Cultural Organization in 2005 [14]. In addition to the cultural inventory in Yogyakarta, Yogyakarta Cultural Office has maintained the existence of a number of these cultures by giving regular rewards to cultural actors such as Cultural 
Award to artists, cultural groups and customary institutions, by providing incentives amounting to IDR 25,000,000 (twenty five million) per person / institution. While the Culture and Tourism Office of Sleman District has conducted inventory and documentation of 60 intangible cultures consisting of 10 traditional ceremonies and 50 cultural traditions.

EBT in Yogyakarta has been documented as local cultures. Although documentation and inventory on EBT have not been well conducted, EBT protection is really important in order to avoid cultural claims by other countries.

\section{CONCLUSION}

The EBT regulation is very important to protect cultures which is considered as invaluable assets in Yogyakarta from other countries' claim.. In Yogyakarta, efforts to establish cultures documentation and inventory have been conducted by Provincial Cultural Office in Yogyakarta as well as Cultural and Tourism Office in Sleman District. Although this effort has not been well implemented but it is a proof of local government's commitment to carry out its responsibilities as referred in the Law on Copyright. Effort to protect and to manage EBT in Yogyakarta, such as culture, traditional ceremonies, existing values of indigenous peoples, as well as tangible and intangible traditional culture, is important reason to avoid claim and misappropriation use by another party/ other country.

\section{REFERENCES}

[1] Antariksa B, "Peluang dan Tantangan Perlindungan Pengetahuan Tradisional dan Ekspresi Budaya TradisionalMakalah yang disampaikan dalam acara Konsinyering Pencatatan Warisan Budaya Takbenda (WBTB) Indonesia", held by Direktorat Jenderal Nilai Budaya, Seni dan Film - Kementerian Kebudayaan dan Pariwisata, Jakarta, 7 October 2011, p. 1

[2] Antons, "Asian Borderlands and the Legal Protection of Traditional Knowledge and Traditional Cultural
Expressions", Modern Asian Studies, Vol. 47, Issue 4, July 2013, pp. 1403-1433

[3] Asri Permata "Perlindungan Dan Pengelolaan Budaya Lokal Di Kota Yogyakarta", e-journal Kajian Hukum. 2016 May $31 ; \operatorname{Vol} 1(1)$

[4] Asri, Dyah Permata Budi. "Implementasi Pasal 38 ayat (1) Undang-Undang Nomor 28 Tahun 2014 terhadap Ekspresi Budaya Tradisional di Kabupaten Sleman." Jurnal Hukum IUS QUIA IUSTUM 23.4 (2016): 612-632.

[5] Bizer, Matthias Lankau, Gerald Spindler, Philipp Zimbehl, "Sui Generis Rights for the Protection of Traditional Cultural Expressions: Policy Implications", The Journal of Intellectual Property, Information Technology and ECommerce Law, 2011, Vol. 2(2): 114-119.

[6] Davis J, Intellectual Property Law, Oxford: Oxford University Press, 2005

[7] Data dari Badan Pusat Statisik (BPS) Nasional Tahun 2014, accessed on 7 May 2015

[8] Fitzgerald, Brian F., and Susan Hedge. "Traditional cultural expression and the internet world." Traditional Knowledge, Traditional Cultural Expression and Intellectual Property in South East Asia. Kluwer, 2008, pp 1-26

[9] Mathiesen, “A Defense of Native Americans', 2016.

[10] Rights over Their Traditional Cultural Expressions", The American Archivist, Vol. 75 (Fall/Winter 2012) pp. 456-481

[11] Purba A,Andrian Krisnawati dan Gazalba Shaleh, TRIP'sWTO dan Hukum HKI Indonesia, Jakarta; Rineka Cipta, 2005

[12] Roisah K, "Perlindungan Ekspresi Budaya Tradisional Dalam Sistem Hukum Hak Kekayaan Intelektual” Jurnal Masalah-masalah Hukum, Fakultas Hukum Universitas Diponegoro, 43 (3), 2014, p. 373

[13] Rahardjo S, Ilmu Hukum, Bandung: PT. Citra Aditya Bakti, 2006.

[14] Vlassis, "European Commission, trade agreements and diversity of cultural expressions: Between autonomy and influence", European Journal of Communication Vol. 31, Issue 4, pp. $446-461,2016$

[15] http://jogja.tribunnews.com/2018/02/02/kunjungan-wisatadiy-tahun-2017-meningkat-signifikan

[16] https://visitingjogja.com/downloads/Buku\%20Statistik\%20 Kepariwisataan\%20DIY\%202016.pdf

[17] Malaysia Sudah Tujuh Kali Mengklaim Budaya Indonesia, https://nasional.tempo.co/read/411954/malaysia-sudahtujuh-kali-mengklaim-budaya-ri, diakses 27 Mei 2018 